\title{
APLIKASI MICROSOFT VISUAL BASIC 6.0 DALAM PEMBUATAN KARTU HASIL STUDI MAHASISWA JURUSAN MATEMATIKA UNIVERSITAS ANDALAS
}

\author{
Yessy Yusnita \\ Program Studi Teknik Sipil, Fakultas Teknik Sipil dan Perencanaan, \\ Institut Teknologi Padang, Padang, Sumatera Barat \\ email: yessyyusnita14@gmail.com
}

\begin{abstract}
Abstrak. Penelitian ini bertujuan membuat algoritma dan pemrograman form Kartu Hasil Studi yang disesuaikan dengan format form Universitas Andalas. Program atau algoritma untuk pembuatan form dibuat dengan menggunakan Microsoft Visual Basic 6.0. Data yang diinput adalah nama mahasiswa, universitas, semester, nomor buku pokok mahasiswa, fakultas, tahun, kode mata kuliah, satuan kredit semester, nilai, bobot, indeks prestasi kumulatif, bobot kumulatif, satuan kredit semester kumulatif, maksimal satuan kredit semester boleh diambil, jumlah satuan kredit semester, jumlah bobot, tanggal, nama dosen, nomor induk pegawai dosen yang sesuai dengan form Kartu Hasil Studi mahasiswa jurusan matematika Universitas Andalas. Dalam pembuatan algoritma form Kartu Hasil Studi tersebut, dibatasi pada data mahasiswa reguler 2014 dan data dosen jurusan matematika Universitas Andalas. Pada form dibuat menu utama seperti Pengolahan Data, Tampilan dan Programmer. Pada form ini tersedia beberapa menu pilihan yang berisi tentang menu proses berfungsi untuk mengisi data mahasiwa dan data dosen secara otomatis; menu hapus berfungsi untuk menghapus data-data yang telah kita input; menu print berfungsi untuk mencetak hasil dari data-data yang telah di input. Menu keluar berfungsi untuk keluar dari form.
\end{abstract}

Kata Kunci: Algoritma dan Pemrograman, Micrososft Visual Basic 6.0, form Kartu Hasil Studi

\begin{abstract}
This study aims to create algorithms and programming Study Result Card form adapted to the form format Andalas University. Program or algorithm to produce form created using Microsoft Visual Basic 6.0. Inputted data is the name of the student, university, semester, the number of books the subject of students, faculty, year, course code, semester credit units, value, weight, grade point average, weighted cumulative, semester credit units cumulative, maximum semester credit units may be loaded, the number of semester credit units, the amount of weight, date, name of the lecturer, lecturer personal identification number that corresponds to the form Card Study Results students majoring in mathematics Andalas University. In the manufacture of algorithms form the Study Result Card, limited to data the regular student 2014 and data lecturer of majoring in mathematics Andalas University. On the main menu form is created as Data Processing, Display and Programmer. In this form is available several menu options on the menu that contains the process serves to fill the data students and faculty the data automatically; menu delete function to delete the data that we have input; menu print function to print the results of the data that has been input. Menu exit serves to get out of the form.

Keywords: Algorithm and Program, Microsoft Visual Basic 6.0, form the card results of the study
\end{abstract}

\section{Pendahuluan}

Perguruan tinggi merupakan kelanjutan pendidikan menengah yang diselenggarakan untuk mempersiapkan peserta didik menjadi anggota masyarakat yang memiliki kemampuan akademis dan profesional. Dalam kegatan perguruan tinggi tidak terlepas dari data-data yang jumlahnya sangat besar. Salah satunya adalah data pada form Kartu Hasil Studi mahasiswa jurusan matematika Universitas Andalas. Kartu Hasil Studi merupakan lembar daftar nilai matakuliah yang telah ditempuh oleh mahasiswa dalam satu semester. Oleh karena itu, untuk menangani data yang besar diperlukan 
suatu program. Salah satu program yang digunakan dalam pembuatan Kartu Hasil Studi ini adalah Microsoft Visual Basic 6.0.

Dalam menangani data yang besar, pemrograman Microsoft Visual Basic 6.0 lebih efektif dibandingkan dengan sistem pemprosesan manual yang pengolahan data menggunakan Microsoft Access dan Microsoft Excel. Semua data yang berkaitan dengan nama mahasiswa, universitas, semester nomor buku pokok mahasiswa, fakultas, tahun, kode matakuliah, SKS, nilai, Bobot, IP kumulatif, Bobot Kumulatif, SKS Kumulatif, Maksimal SKS boleh diambil, jumlah SKS, jumlah bobot, tanggal, nama dosen, nomor induk pegawai dosen dapat disimpan dalam kedua program tersebut di atas. Seiring berjalannya waktu, maka data yang disimpan juga semakin banyak. Petugas yang mengoperasikannya pun semakin lama akan merasa jenuh karena data yang berjejal memenuhi layar komputer. Setiap tahun ajaran baru, program yang baru mulai dibuat untuk mengisi perubahan data seiring dengan pergantian mahasiswa yang baru masuk.

Menurut (Widodo \&Aris P, 2004) Program Microsoft Access dan Microsoft Excel mempunyai beberapa kelemahan dan kelebihan dalam pengolahan basis data antara lain dalam Microsoft Access kelebihannya adalah dilihat dari perspektif programmer adalah kompatibilitasnya dengan bahasa pemrograman Structured Query Language (SQL). Para pengguna dapat mencampurkan dan menggunakan kedua jenis bahasa tersebut (VBA dan Macro) untuk memprogram form dan logika dan juga untuk mengaplikasikan konsep berorientasi objek, sedangkan kelemahannya adalah hasil program yang kita buat harus disertakan software Access, tidak dapat berdiri sendiri, dan menu pilihannya sudah tersusun dalam program tanpa perlu kita buat sendiri. Sedangkan menurut (Rusdi, 2017) dalam Microsoft Visual Basic 6.0, program yang kita buat bisa berdiri sendiri dengan membuat setupnya karena dalam Microsoft Visual Basic 6.0 terdapat fasilitas menu pilihan yang bisa kita atur sesuai dengan kebutuhan.

Sedangkan menurut (Widodo \& Aris P, 2004) Microsoft Excel kelebihannya adalah 1. Excel dapat mengurutkan data dengan mudah, 2. Excel dapat mengedit teks secara langsung di sel, 3. Berbasis window, 4. Dapat mencetak dengan proporsi berbeda, 5. Dapat menjumlah secara otomatis dengan menggunakan autosum, 6. Dapat membuat grafik secara mudah dan cepat melalui fungsi Chart Wizard, 7. Dapat menjumlahkan grand total dan sub total dengan mudah sekali. Sedangkan kelemahannya adalah dalam proses pencarian data kurang cepat dan dalam proses pengeditan kita harus memblok data yang akan kita edit kemudian kita hapus dan baru proses pengeditan dapat berlangsung. Microsoft Visual Basic 6.0 memberikan kemudahan dalam proses pencarian data, proses dapat kita atur sesuai yang kita inginkan tanpa memblok data yang akan kita edit melalui bahasa pemrograman. Dengan menggunakan pemrograman Microsoft Visual Basic 6.0 peneliti tertarik untuk menggunakan aplikasi Microsoft Visual Basic 6.0 dalam pembuatan Kartu Hasil Studi mahasiswa jurusan matematika Universitas Andalas.

\section{Landasan Teori}

\section{Pengenalan Visual Basic 6.0}

Visual Basic 6.0 merupakan bahasa pemrograman yang sangat mudah dipelajari, dengan teknik pemrograman visual yang memungkinkan penggunanya untuk berkreasi lebih baik dalam menghasilkan suatu program aplikasi. Ini terlihat dari dasar pembuatan dalam visual basic adalah form, dimana pengguna dapat mengatur tampilan form kemudian dijalankan dalam script yang sangat mudah (Kanedi \& Jauhari, 2013).

Beberapa kemampuan dari Visual Basic 6.0 antara lain sebagai berikut (Razaq, 2004):

1. Membuat program aplikasi berbasis window.

2. Membuat objek-objek pembantu program, misalnya File, Help dan sebagainya.

3. Menguji program dan menghasilkan program akhir yang langsung dapat dijalankan .

\section{Menjalankan Visual Basic 6.0}

Visual Basic 6.0 merupakan salah satu aplikasi yang berada dalam Windows, sehingga untuk menjalankannya terlebih dahulu harus mengaktifkan Windows. Adapun langkah-langkah untuk menjalankan Visual Basic 6.0 (Trisnawati, 2016): 
1. Klik tombol Start, arahkan pada pilihan All Programs.

2. Arahkan mouse pada grup Microsoft Visual Basic 6.0, kemudian pilih Microsoft Visual Basic 6.0.

3. Pilih Standard EXE, kemudian klik Open.

\section{Mengenal Lingkungan Visual Basic 6.0}

Bagian-bagian yang penting dari lingkungan pengembangan Visual basic 6.0 dijelaskan sebagai berikut (Akbar, Ismail \& Dahlan, 2013):

\section{Menu Bar}

Мепи Bar menampilkan menu perintah pengembangan aplikasi yang berfungsi untuk melakukan tugas dan kegiatan tertentu, yang terdiri dari File, Edit, View, Windows, Project, Format, Debuq, Run, Query, Diagram, Tool, Add-ins, Windows dan Help.

\section{Jendela Properties}

Jendela Properties dapat ditampilkan dengan cara klik kanan pada mouse dan pilih properties. Jendela Properties menampilkan daftar properti dan nilai properti yang dapat digunakan untuk merubah bentuk objek sesuai dengan keinginan pengguna.

\section{Toolbar}

Toolbar terdiri dari tombol-tombol yang digunakan untuk menjalankan suatu perintah dengan cepat. Perintah yang digunakan untuk mengaktifkan atau menyembunyikan toolbar tersebut dalah dengan memilih View $\rightarrow$ Toolbar, kemudian klik salah satu toolbar yang diinginkan.

\section{Toolbox}

Toolbox berisi beberapa objek atau kontrol yang dibutuhkan dalam aplikasi yang diletakkan dalam suatu form. Kontrol inilah sebagai penghubung antara program aplikasi dengan pengguna.

\section{Jendela Form Layout}

Jendela Form Layout adalah jendela yang menggambarkan posisi form dalam layar monitor. Dengan tampilan tersebut pengguna dapat melihat posisi aplikasi yang dibuat saat dijalankan dalam layar monitor.

\section{Jendela Project Explorer}

Jendela Project Explorer berisi semua file yang ada dalam aplikasi Visual Basic 6.0. Setiap projek bisa terdiri atas beberapa file.

\section{Jendela Kode}

Jendela Kode merupakan tempat untuk membuat kode yang merupakan instruksi dalam aplikasi Visual Basic 6.0. untuk membukanya dapat dilakukan dengan cara mengklik ganda pada objek yang akan diberi kode atau klik kanan form, lalu pilih View Code dari Jendela Project Explorer.

\section{Tipe Data}

Di dalam pembuatan program aplikasi dengan Visual Basic 6.0 tidak terlepas dengan jenis data. Pemilihan jenis data yang tepat akan berguna untuk menghemat memori, meningkatkan kecepatan proses dan ketelitian dalam perhitungan. Jenis data tersebut dapat dilihat pada tabel 1 berikut (Enterprise, 2015).

Tabel 1. Tipe Data

\begin{tabular}{lll}
\hline \multicolumn{1}{c}{ Tipe } & Keterangan & Range \\
\hline Integer & Tipe data numerik yang berupa bilangan bulat & -32768 s.d 32767 \\
Single & Tipe data numerik yang berupa pecahan & $-3.4028823+38$ s.d $3.4028823+38$ \\
String & $\begin{array}{l}\text { Tipe data yang memiliki nilai apfanumerik } \\
\text { (angka, huruf, dan karakter khusus) }\end{array}$ & 0 s.d 2milyar karakter \\
& & \\
\hline
\end{tabular}




\section{Variabel}

Variabel adalah tempat dalam memori komputer yang telah diberi nama dan bersifat sementara. Sebelum menggunakan variabel, harus dideklarasikan terlebih dahulu. Hal ini yang perlu diperhatikan dalam pendeklarasian adalah (Rusmawan, 2013):

a. Diawali dengan Statemen Dim

b. Menentukan Jenis variabel

c. Penulisan Pendeklarasian variabel

\section{Konstanta}

Konstanta adalah suatu nilai tetap yang tidak dapat dirubah dalam suatu aplikasi (Harpiandi, 2004). Konstanta dapat berupa teks atau angka, seperti : Konstanta String. Konstanta alfanumerik ini ditulis dengan diapit oleh tanda kutip ganda, misalnya: Text10.Text = "13", Text1.Text = "MIPA/MATEMATIKA".

\section{Form}

Agar program ini memiliki kemampuan MDI yaitu kemampuan menampilkan beberapa form sekaligus, maka menu utama harus dibuat dengan MDI Form. Karena form yang ada pada lembar kerja bukan bertipe MDI, maka form kosong tersebut harus dihapus dengan cara mengklik kanan nama form dikotak Project lalu klik Remove Forml. MDI Form digunakan sebagai form utama atau form induk, dimana semua form pendukung (form child) program ini berada pada area MDI Form tapi tidak dapat keluar pada area tersebut (Kusumo, 2003).

\section{Pembahasan}

Kartu Hasil Studi berisi tentang nama Universitas, Semester, Nama mahasiswa, Fakultas, Tahun, Nomor Buku Pokok (No.BP) Mahasiswa, Jumlah Sistem Kredit Semester (SKS) dari banyaknya mata kuliah yang diambil mahasiswa dalam suatu semester, baik semester genap maupun semester ganjil beserta kode mata kuliah tersebut, Bobot, beban studi dan Indeks Prestasi (IP). Algoritma pada form Kartu Hasil Studi ditulis pada jendela kode yang muncul setelah melakukan klik ganda pada tombol proses.

Event klik dideklarasikan dengan mengetik perintah program Private sub cmdProses dan End $s u b$, yang menunjukkan bahwa dengan mengklik tombol proses maka program Kartu Hasil Studi akan dijalankan. Deklarasi variabel pada Kartu Hasil Studi yang dimaksudkan untuk menentukan nama variabel beserta jenis dari variabel tersebut. Pendeklarasian variabel pada Kartu Hasil Studi diletakkan dalam prosedur, sehingga variabel hanya digunakan oleh prosedur event pada Kartu Hasil Studi. Pada algoritma ini dideklarasikan SKS, SKS_KUM, SKS_Boleh_Diambil dengan jenis data Integer, JUMLAH_SKS, BOBOT, BOBOT_KUM, JUMLAH_BOBOT, IP, IP_KUM dengan jenis data Single dan HURUF dengan jenis data String.

\section{Algoritma Deklarasi Event dan Variabel}

Algoritma ini berisikan tentang pendeklarasian event dan variabel pada form Kartu Hasil Studi.

Algoritma 1. Deklarasi Event dan Variabel

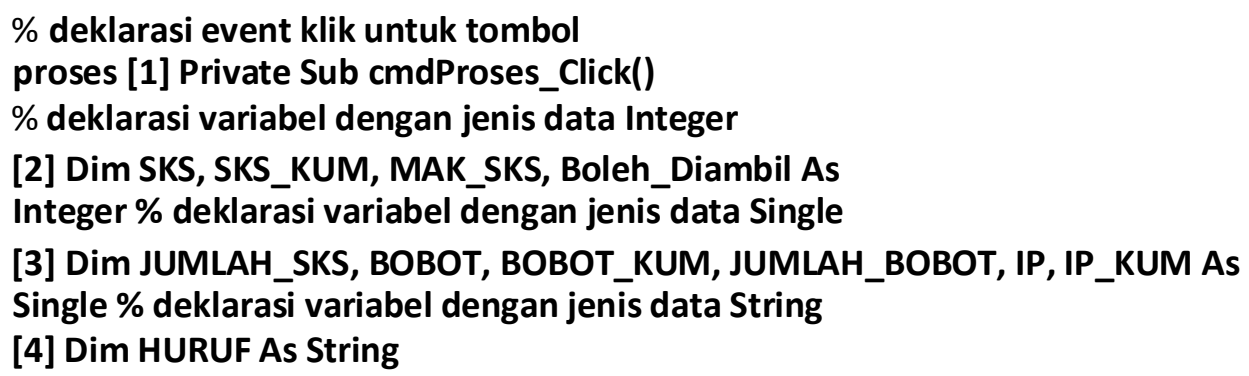




\section{Algoritma Data Konstan}

Algoritma data konstan bertujuan agar kode fakultas atau program studi, semester dan tahun langsung tampil dalam form pada saat algoritma ini dijalankan.

Algoritma 2. Deklarasi Event dan Variabel

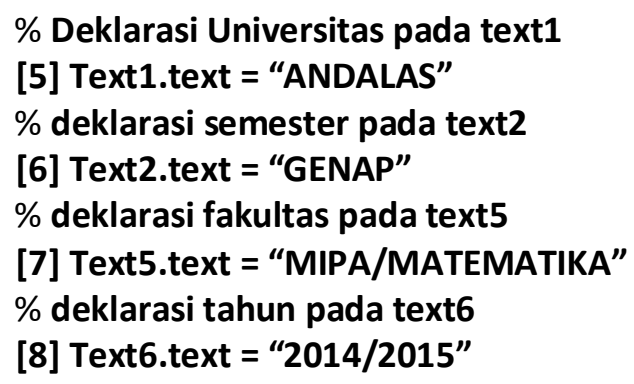

\section{Algoritma Baca Data}

Agoritma Baca Data bertujuan untuk membaca data yang diberikan (diinput dari keyboard), sehingga bila algoritma ini dijalankan data-data mahasiswa yang bersangkutan akan langsung ditampilkan pada form Kartu Hasil Studi.

\section{Algoritma Baca Data Nomor BP}

Pada waktu algoritma atau program dijalankan, pengguna terlebih dahulu membaca data Nomor BP yang diberikan (diinput dari keyboard), sehingga nama mahasiswa yang bersangkutan akan langsung ditampilkan di dalam form Kartu Hasil Studi.

Algoritma 3. Baca Data Nomor BP

\begin{tabular}{|l}
\hline \% jika Nomor BP tertulis ditext4 maka nama \\
mahasiswa tertulis ditext7 \\
[9] If (Text4.Text = "1410431025") Then \\
Text7.Text = "Eko Fachrozi Putra" \\
End If \\
[10] If (Text4.Text = "1410432049") Then \\
Text7.Text = "Windi Adrian Sukri" \\
End If \\
[11] If (Text4.Text = "1410431046") Then \\
Text7.Text = "Nurmaylina Zaja" \\
End If \\
[12] If (Text4.Text = "1410431040") Then \\
Text7.Text = "Zahratul Aini"" \\
End If \\
[13] If (Text4.Text = "1410431008") Then \\
Text7.Text = "Siti Juriah" \\
End If
\end{tabular}

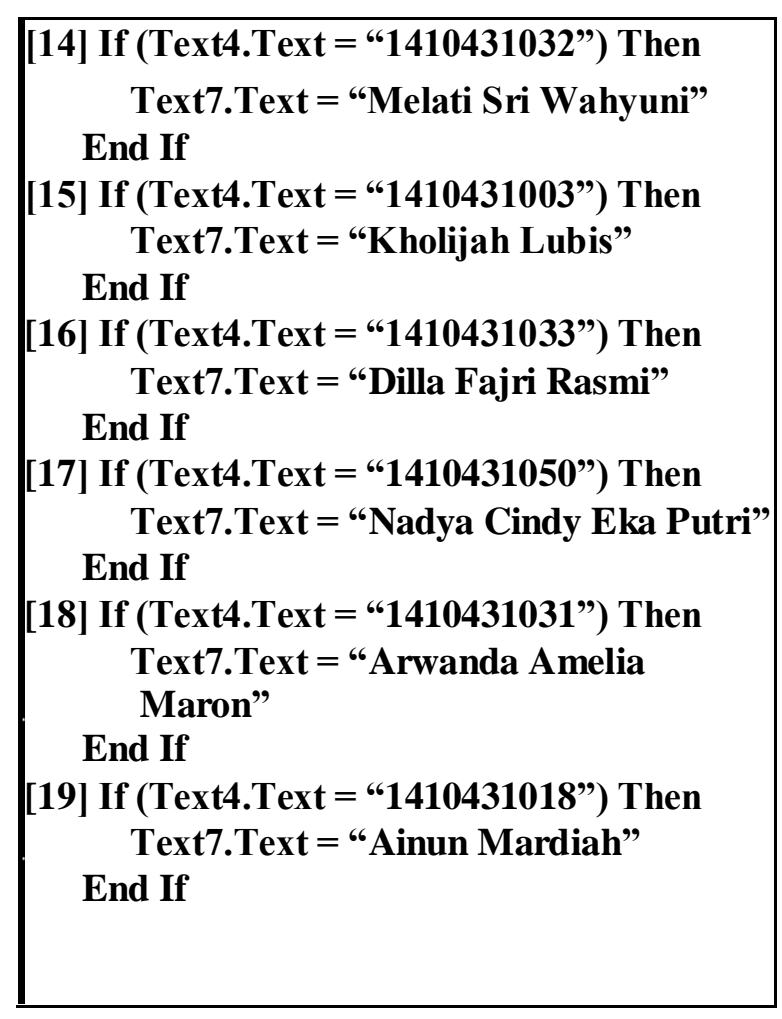



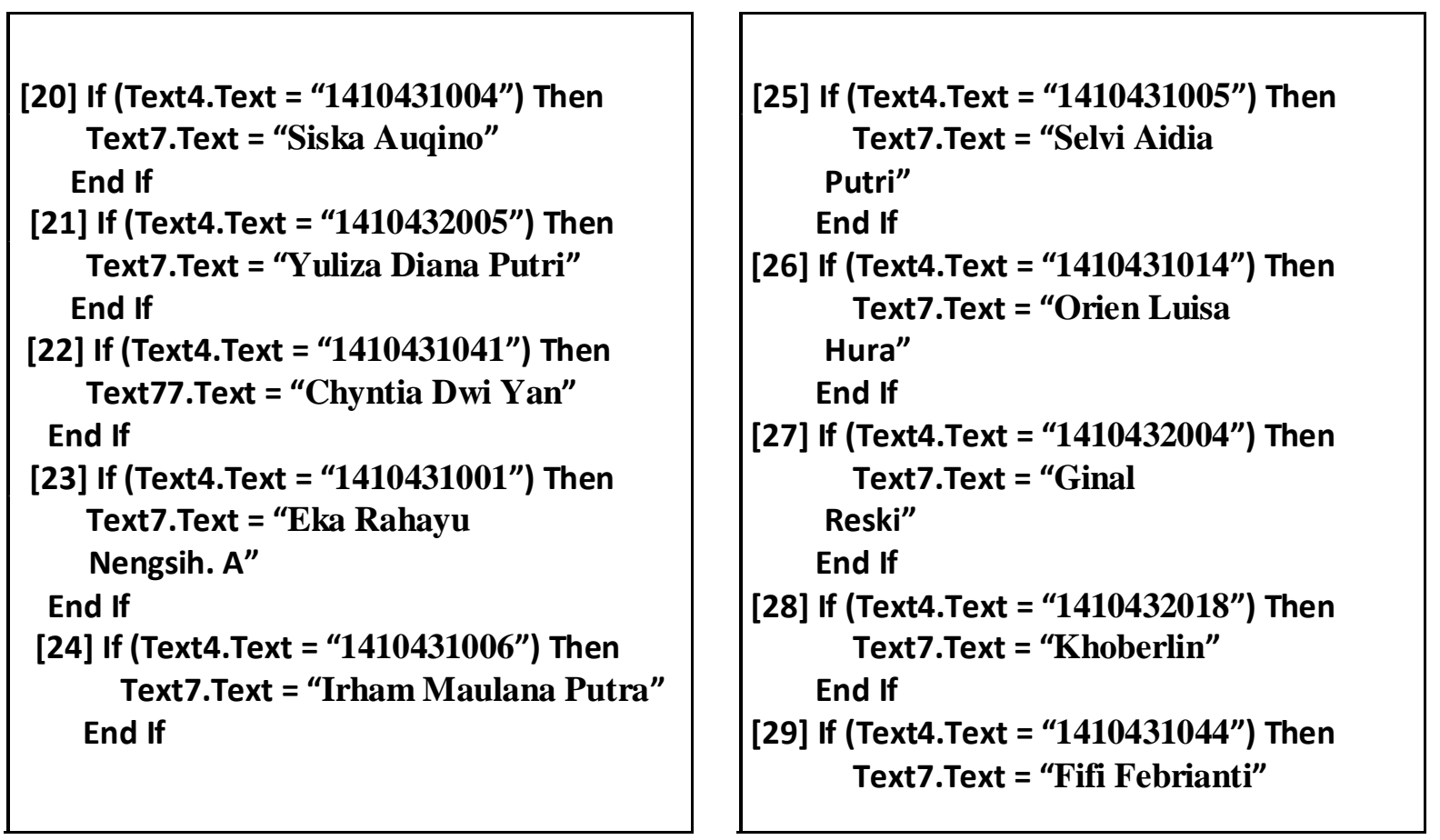

\section{Algoritma Baca Data Nama Mata Kuliah}

Pada waktu algoritma atau program dijalankan, pengguna terlebih dahulu harus memilih salah satu nama mata kuliah pada Combo1, sehingga kode mata kuliah dan jumlah SKS mata kuliah tersebut akan langsung ditampilkan pada form Kartu Hasil Studi.

Algoritma 4. Baca Data Nama Mata Kuliah

\% jika Nama Mata Kuliah dipilih pada Combo1, maka Kode Mata Kuliah dan jumlah SKS mata kuliah langsung ditampilkan pada text.

[30] If (Combo1.Text = "AGAMA") Then

Text8. Text $=$ "HKU 141"

Text20.Text $=$ " 2 "

[31] If (Combo1.Text = "FISIKA DASAR") Then

Text8.Text $=$ "PAP 111"

Text20.Text $=$ "3"

[32] If (Combo1.Text = "KIMIA DASAR") Then

Text8. Text $=$ "PAK 111"

Text20.Text $=$ "3"

[33] If (Combo1.Text = "BAHASA

INGGRIS MATEMATIKA") Then

Text8. Text $=$ "PAM 111"

Text20.Text $=$ "3"
[34] If (Combo1.Text = "KALKULUS I") Then

Text8. Text $=$ "PAM 121"

Text20.Text $=$ " 4"

[35] If $($ Combo1.Text $=$ "PENGANTAR

MATEMATIKA") Then

Text8. Text $=$ "PAM 123"

Text20.Text $=$ "4"

[36] If (Combo1.Text = "BAHASA

INDONESIA") Then

Text8. Text $=$ "SSI 121"

Text20. Text $=$ "2"

[37] If (Combo1.Text = "ALJABAR

LINEAR ELEMENTER") Then

Text8. Text = "PAM 231"

Text20.Text $=$ "4"

[38] If (Combo1.Text $=$ "KALKULUS

PEUBAH BANYAK") Then

Text8. Text $=$ "PAM 241"

Text20.Text $=$ "4" 

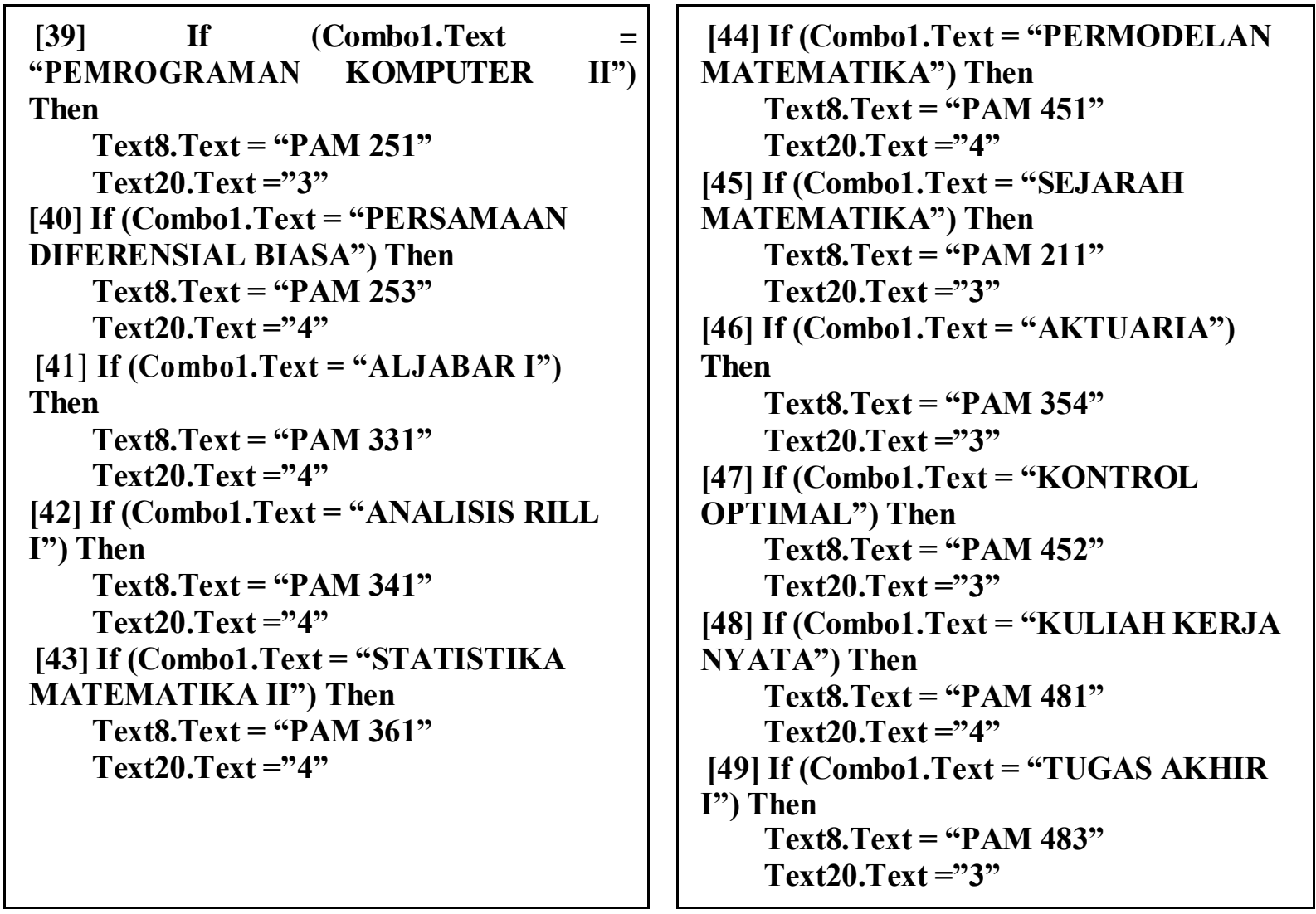

Algoritma Baca Data Nama Mata Kuliah ini terdiri dari Combo1 sampai Combo6 untuk memilih judul mata kuliah dan Combo7 sampai Combo12 berfungsi untuk memilih nilai yang diperoleh. Algoritma Combo1 dapat dilihat pada algoritma 4 di atas. Setiap Combo memiliki nomor text yang berbeda, dimana setiap text akan diisi pada kode mata kuliah, SKS dan BOBOT. Bila judul mata kuliah dipilih pada Combo1 maka pada text8 akan ditampilkan kode mata kuliah, pada text20 akan ditampilkan jumlah SKS mata kuliah tersebut.

\section{Algoritma Mencari Jumlah SKS dan Jumlah Bobot}

Algoritma ini berisikan rumus untuk menghitung Jumlah SKS dan Jumlah Bobot.

Algoritma 5. Mencari Jumlah SKS dan Jumlah Bobot

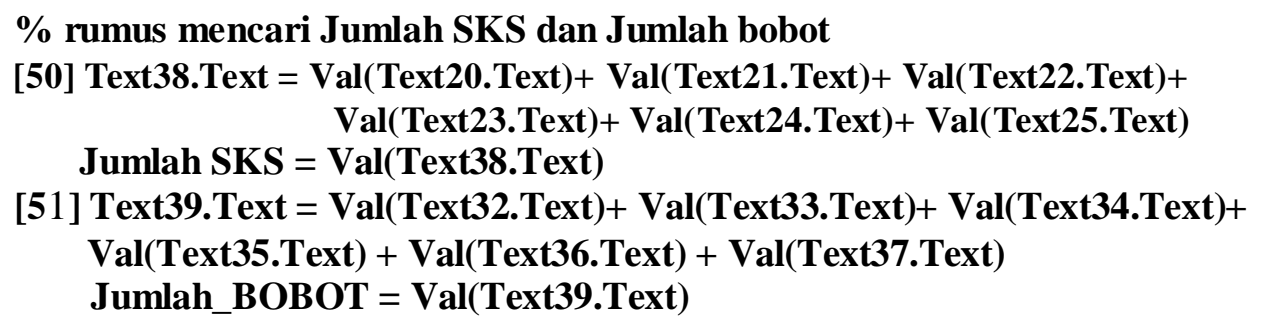




\section{Algoritma Mencari IP, IP KUM, BOBOT KUM dan SKS KUM}

Algoritma ini berisikan rumus untuk mencari IP, IP KUM, Bobot KUM dan SKS KUM pada form Kartu Hasil Studi.

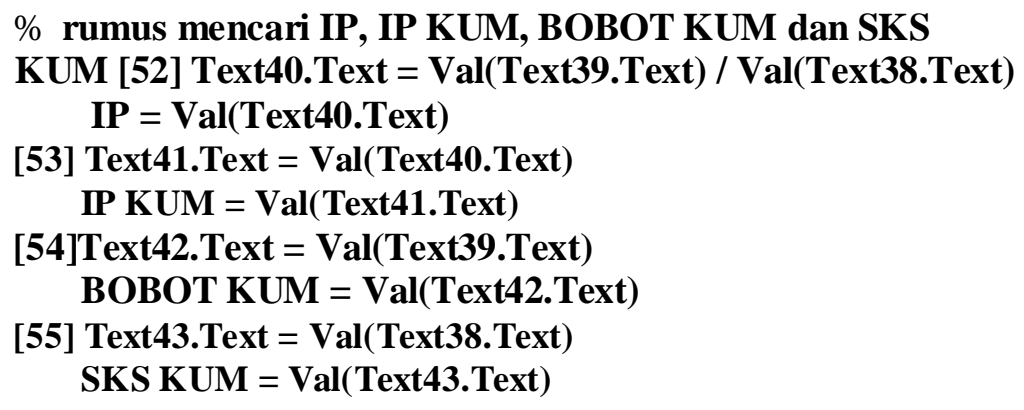

\section{Algoritma Mencari Maks SKS Boleh Diambil}

Algoritma ini berisikan logika untuk mencari Maks SKS Boleh Diambil

Algoritma 7. Mencari Maks SKS Boleh Diambil

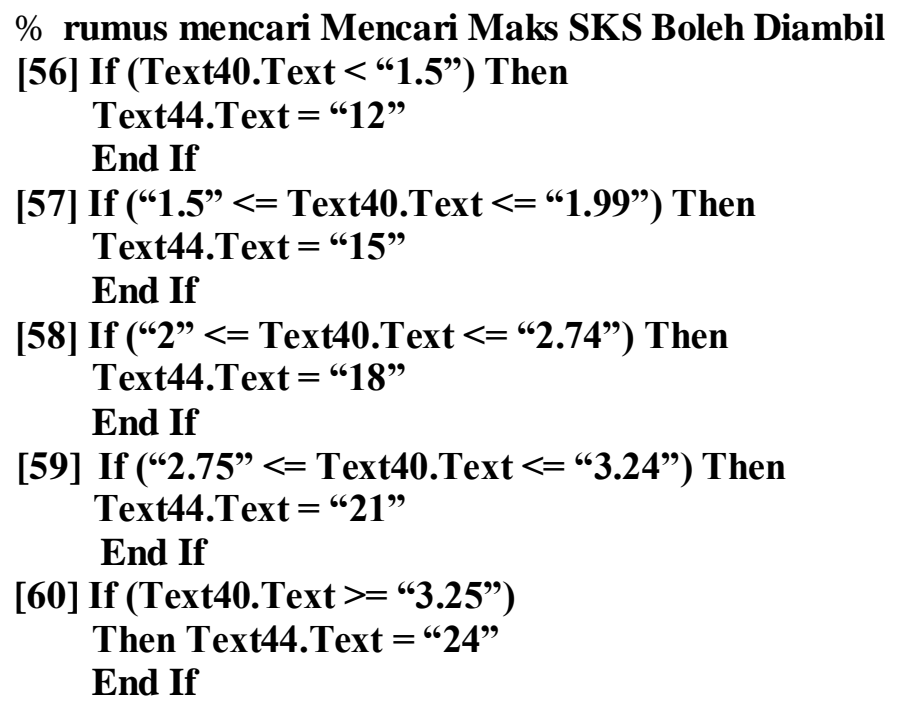

\section{Algoritma Tombol Hapus}

Algoritma ini digunakan untuk menghapus data yang telah ditampilkan pada form, kemudian pada form akan tampil lembaran kososng yang siap untuk mengisi data baru. 
Algoritma 8. Tombol Hapus

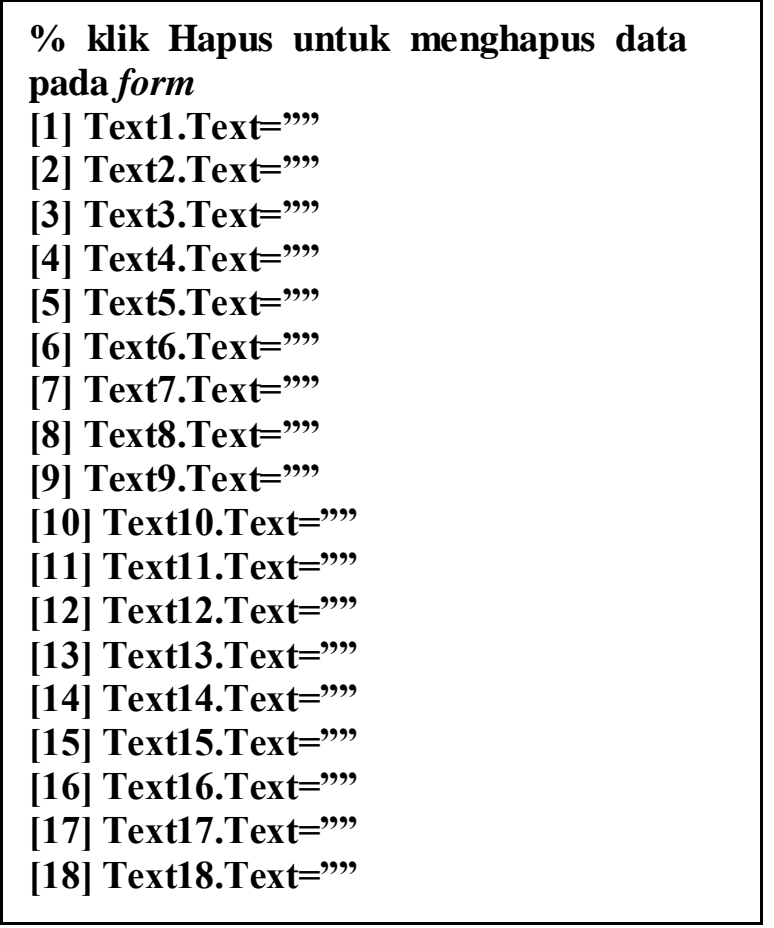
[19] Text19.Text="",
[20] Text20.Text=""
[21] Text21.Text=""
[22] Text22.Text="",
[23] Text23.Text=""
[24] Text24.Text=""
[25] Text25.Text=""
[26] Text26.Text=""
[27] Text27.Text=""
[28] Text28.Text=""
[29] Text29.Text="'"
[30] Text30.Text="'
[31] Text31.Text=""
[32] Text32.Text="",
[33] Text33.Text=""
[34] Text34.Text="',
[35] Text35.Text="",
[36] Text36.Text="',
[37] Text37.Text=""
End Sub

\section{Algoritma Tombol Print}

Algoritma tombol Print digunakan untuk mencetak form Kartu Hasil Studi

Algoritma 9. Tombol Print

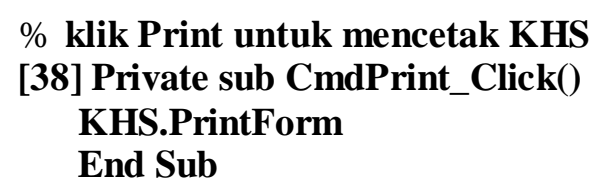

Algoritma Tombol Keluar

Algoritma tombol Keluar bertujuan untuk menutup form Kartu Hasil Studi

Algoritma 10. Tombol Keluar

\begin{tabular}{|l|}
\hline$\%$ klik Keluar untuk menutup form KHS \\
[39] Private sub CmdKeluar_Click() \\
Unload Me \\
End Sub \\
\hline
\end{tabular}

\section{Algoritma ComboBox}

ComboBox pada program ini berupa daftar nama mata kuliah dan daftar nama dosen jurusan Matematika. 
\% daftar nama mata kuliah (sampai

Combo15) Private Sub Form_Load()

[40] Combo1.AddItem "(...semester 1....)"

[41] Combo1.AddItem "AGAMA"

[42] Combo1.AddItem "FISIKA DASAR"

[43] Combo1.AddItem "KIMIA DASAR"

[44] Combo1.AddItem "BAHASA INGGRIS MATEMATIKA"

[45] Combo1.AddItem "KALKULUS I"

[46] Combo1.AddItem "PENGANTAR MATEMATIKA"

[47] Combo1.AddItem "BAHASA INDONESIA"

[48] Combo1.AddItem "(...semester 3...)"

[49] Combo1.AddItem "ALJABAR LINIER ELEMENTER"

[50] Combo1.AddItem "KALKULUS PEUBAH BANYAK"

[51] Combo1.AddItem "PEMROGRAMAN KOMPUTER II"

[52] Combo1.AddItem "PERSAMAAN DIFERENSIAL BIASA"

[53] Combo1.AddItem "AKONTROL OPTIMAL"

[54] Combo1.AddItem "(...semester 5...)"

[55] Combo1.AddItem "ALJABAR I"

[56] Combo1.AddItem "ANALISIS RIIL I"

[57] Combo1.AddItem "STATISTIKA MATEMATIKA II"

[58] Combo1.AddItem "SEJARAH MATEMATIKA"

[59] Combo1.AddItem "AKTUARIA"

[60] Combo1.AddItem "(...semester 7...)"

[61] Combo1.AddItem "PERMODELAN MATEMATIKA"

[62] Combo1.AddItem "KULIAH KERJA NYATA"

[63] Combo1.AddItem "TUGAS AKHIR I"

$\%$ daftar nilai (sampai Combo12)

[65] Combo7.AddItem " $A$ "

[66] Combo7.AddItem "A-"

[67] Combo7.AddItem " $B$ "

[68] Combo7.AddItem "B-"

[69] Combo7.AddItem " $\mathrm{C}+$ "

[70] Combo7.AddItem " $\mathrm{C}$ "

[71] Combo7.AddItem "C-"

[72] Combo7.AddItem " $D$ "

[73] Combo7.AddItem "E"

$\%$ daftar nama dosen jurusan Matematika

[74] Combo7.AddItem "Dr. Admi Nazra"

[75] Combo7.AddItem "Dr. Ahmad Iqbal Baqi"

[76] Combo.AddItem "Dr. Arrival Rince Putri"

[77] Combo16.AddItem "Budi Rudianto, M.Si"

[78] Combo16.AddItem "Bukti Ginting, M.Si"

[79] Combo16.AddItem "Dr. Des Welyyanti"

[80] Combo16.AddItem "Dr. Dodi Devianto"

[81] Combo16.AddItem "Efendi, M.Si"

[82] Combo16.AddItem "Dr. Effendi"

[83] Combo16.AddItem "Dr. Ferra Yanuar"

[84] Combo16.AddItem "Dr. Haripamyu"

[85] Combo16.AddItem "Hasmira Yozza, M.Si"

[86] Combo16.AddItem "Prof. Dr. I Made Arnawa" 


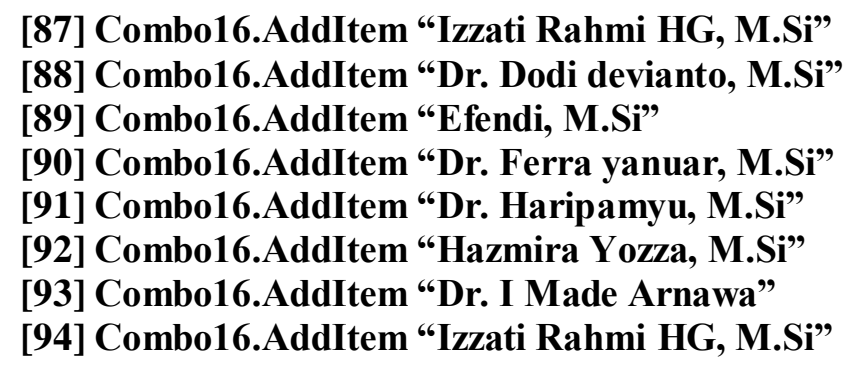

Berikut ini adalah tampilan form Kartu Hasil Studi dalam program Visual Basic 6.0 :

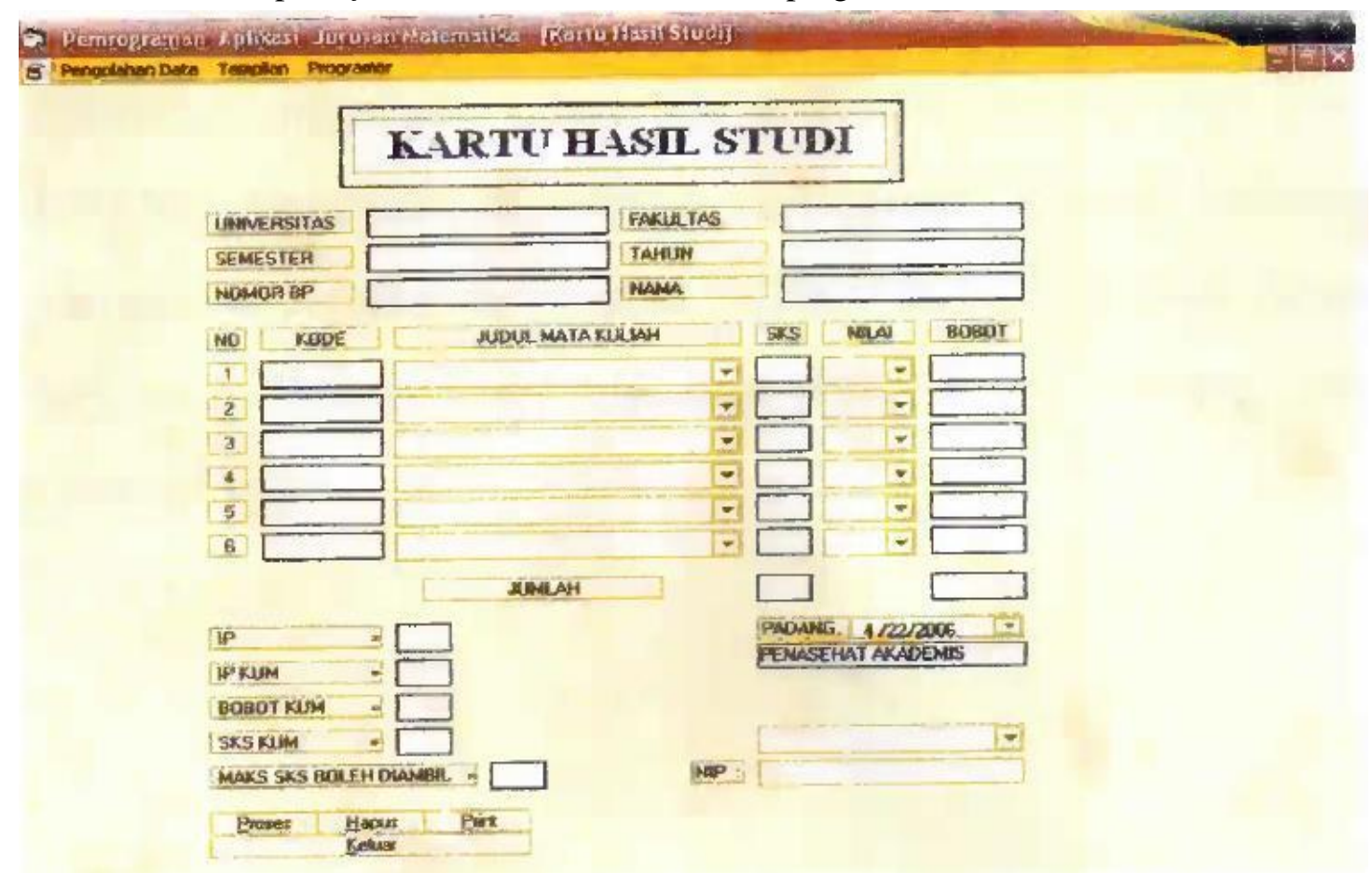

Gambar 1. Form Kartu Hasil Studi

\section{Kesimpulan dan Saran}

Proses kerja dari program berdasarkan pada struktur sistem dan kebenaran data tergantung pada pengguna. Pada form Kartu Hasil Studi dibuat menu utama seperti Pengolahan Data, Tampilan dan Programmer. Pada form Kartu Hasil Studi tersedia menu untuk mengisi nama mahasiswa, universitas, semester, nomor buku pokok mahasiswa, fakultas, tahun, kode matakuliah, satuan kredit semester, nilai, bobot, indeks prestasi kumulatif, bobot kumulatif, satuan kredit semester kumulatif, Maksimal satuan kredit semester boleh diambil, jumlah satuan kredit semester, jumlah bobot, tanggal, nama dosen, nomor induk pegawai dosen yang sesuai dengan form Kartu Hasil Studi mahasiswa jurusan matematika Universitas Andalas. Pada form ini tersedia beberapa menu pilihan yang berisi tentang menu proses berfungsi untuk mengisi data mahasiwa dan data dosen secara otomatis; menu hapus berfungsi untuk menghapus data-data yang telah kita input; menu print berfungsi untuk mencetak hasil dari data-data yang telah di input. Menu keluar berfungsi untuk keluar dari form.

Saran yang diusulkan adalah penelitian selanjutnya dapat membuat beberapa form. Kemudian dibuat adanya keterkaitan antara form yang satu dengan lainnya pada program aplikasi ini. 


\section{Daftar Pustaka}

Akbar, Ismail \& Dahlan, A. (2013). Pembuatan Sistem Informasi Penjualan Pada Ade Jaya Ponsel Dengan Menggunakan Visual Basic. Jurnal Ilmiah DASI, 14(4), 39-43. Retrieved from https://media.neliti.com/media/publications/195997-ID-pembuatan-sistem-informasi-penjualanpad.pdf

Enterprise, J. (2015). Pemrograman Visual basic 6.0. Yogyakarta: Alex Media Komputindo.

Harpiandi. (2004). Pemrograman Database dengan ADO Menggunakan Visual Basic 6.0. Jakarta: PT. Elex Media Komputindo.

Kanedi, Jauhari, E. al. (2013). Tata Kelola Perpustakaan Menggunakan Bahasa Pemrograman Visual Basic 6.0 (Studi Kasus Pada Sekolah Menengah Pertama Negeri 3 Seluma). Media Infotama, 9(1), 46-55. Retrieved from

https://www.google.com/url?sa=t\&rct=j\&q=\&esrc=s\&source=web\&cd=1\&cad=rja\&uact=8\&ve $\mathrm{d}=2$ ahUKEwit_pTL9YHhAhV46nMBHY0WAIgQFjAAegQIChAC\&url=https\%3A\%2F\%2Fjur nal.unived.ac.id\%2Findex.php\%2Fjmi\%2Farticle\%2Fview\%2F26\%2F24\&usg=AOvVaw0qMfQ ukEDIA7tzHHcz2ohQ

Kusumo, A. S. (2003). Microsoft Visual Basic 6.0. Jakarta: PT. Elex Media Komputindo.

Razaq, A. (2004). Belajar Cepat Langsung Praktek Visual basic 6.0. Surabaya: INDAH.

Rusdi, M. (2017). Penggunaan Visual Basic 6.0 Dalam Penggajian Karyawan Pada CV. Usaha Bersama. Technologia, 2(2), 118-123. Retrieved from http://ojs.uniska-bjm.ac.id

Rusmawan, U. (2013). Visual Basic 6.0 Untuk Semua Tingkatan. Yogyakarta: Alex Media Komputindo.

Trisnawati, H. (2016). NoSistem Informasi Inventory Pada PT Vision Net Menggunakan Visual Basic 6.0. Sains Dan Teknologi Universitas Tama, XI(1), 27-32. Retrieved from http://jagakarsa.ac.id

Widodo, Aris P, dkk. (2004). Buku Ajar Basis Data. Semarang: Jurusan Matematika FMIPA UNDIP. 